\title{
Optimum Composition of Charter Contracts for the Renewal of the Fleet of Offshore Support Vessels Considering Uncertainties: A Literature Review
}

\author{
Marcelo Oliveira de Souza ${ }^{1}$, Guilherme Luis Roehe Vaccaro ${ }^{1}$, Luiz Alberto Oliveira Rocha ${ }^{1}$, Giulio Lorenzini ${ }^{2 *}$ \\ ${ }^{1}$ Universidade do Vale do Rio dos Sinos, Engenharia de Produção e Sistemas, Av. Unisinos, 950, Cristo Rei, São Leopoldo, \\ RS, CEP: 93.022-750, Brazil \\ ${ }^{2}$ Università degli Studi di Parma, Dipartimento di Ingegneria e Architettura, Parco Area delle Scienze 181/A, 43124 Parma, \\ Italy
}

Corresponding Author Email: giulio.lorenzini@unipr.it

https://doi.org/10.18280/ijht.370201

Received: 13 April 2019

Accepted: 27 May 2019

\section{Keywords:}

maritime chartering, offshore support vessels, optimization under uncertainties, prices prediction, risk analysis

\begin{abstract}
This article reviews the literature on the Mendeley, Science Direct and Scopus databases on solutions to the optimal composition problem of offshore support charter contracts published between 2008 and 2018. This problem is relevant to the ongoing fleet renewal process, in terms of associated costs and fleet flexibility, in the context of oil and gas exploration and production. The problem is subject to uncertainties related to the demand to be met and to charter prices. The literature presents solutions that can be applied to parts of the problem, however a satisfactory integral solution was not found. The analysis of the literature and the characteristics of the problem indicate the construction of a solution multi-approach method as a viable way to treat the complexity of the problem.
\end{abstract}

\section{INTRODUCTION}

The exploration and production of oil and gas (E\&P) forms the basis of the oil industry. Resources of the order of US\$ 1.7 trillion are invested annually in technological development, extension of geological knowledge and formation of the chain of goods and support services [1-2]. The industry is characterized by high volumes produced and moved, as well as revenues and costs of the order of tens of billions of dollars per year. Most of the oil and gas reserves are found in maritime fields in countries such as Brazil and Norway, generating comparatively greater costs of exploration and production in relation to countries with reserves onshore, such as Venezuela and Saudi Arabia.

Several maritime units (MUs) are required for exploration and production in a maritime field, in addition to offshore support vessels, responsible for supplying these units. The two main types of offshore units are: drilling rigs - units designed to drill and complete oil and natural gas exploration or production wells; and Stationary Production Units (SPUs) - units positioned in fields already discovered for the extraction of oil and natural gas. The rental of a probe is estimated at between $\$ 200,000$ and $\$ 500,000$ per day [3], depending on the contextual conditions of the oil and gas market. The main offshore support vessel is Platform Supply Vessel (PSV), whose daily rent is between $\$ 15,000$ and $\$ 43,000$ [4], depending on its capacity. As an illustration, on the Brazilian coast, in July 2017, there were 20 exploratory wells completed (i.e., the activities to determine the existence of oil and gas and their viability of production were finalized) and 15 exploratory wells in activity. During the same month, 143 SPUs were in operation, 62 of them in the Campos basin [5]. The logistical process to make maritime E\&P activities feasible therefore presents considerable complexity and costs, particularly considering the climatic effects and the general context of installed capacity below the demand of certain types of vessels, requiring a greater refinement of planning.

In this context, maritime transport deserves special attention on the part of decision makers, not only because it represents up to $80 \%$ of the total cost of the chain [6], but also due to the complexity of the activities and decisions involved. The first decision concerns the formation of the fleet of offshore support vessels to supply the E\&P maritime units. It is necessary to decide on: the types of vessels and the necessary quantities of each; whether the vessels will be owned or chartered; and, if charted, what types of contracts and for what time horizons will be realized. The goal is to minimize costs and risks, leading oil and gas companies to have the smallest fleet possible to adequately meet the supply needs of their MUs.

The demand for vessels depends on the number of active MUs and their consumption profile of supplies. However, the number of MUs depends on the existing production (and exploration) fields or the ones to be developed or acquired in the future. In addition, the classes and quantities of vessels required may vary over time, depending on the actors and technologies available on the market. Thus, in order to guarantee the maintenance of service levels to the MUs at the lowest possible cost, the fleet must be flexible, and this flexibility can be obtained by the proper composition of maritime charter contracts.

The problem of optimal composition of charter contracts for vessels supporting MUs, in terms of contract, is to identify the value of the mix of contracts in order to minimize the costs and risks involved and guarantee the supply of MUs with acceptable levels of service.

Many factors need to be taken into account when defining the best set of charter contracts (modalities, quantities and 
durations of contract). Among these factors, the following stand out: (i) Offshore support logistics; (ii) Demand to be served; (iii) Chartering prices; and (iv) Legislation and regulation of maritime transport [6-11]. Figure 1 shows the relationship between these four factors in the definition of the problem.

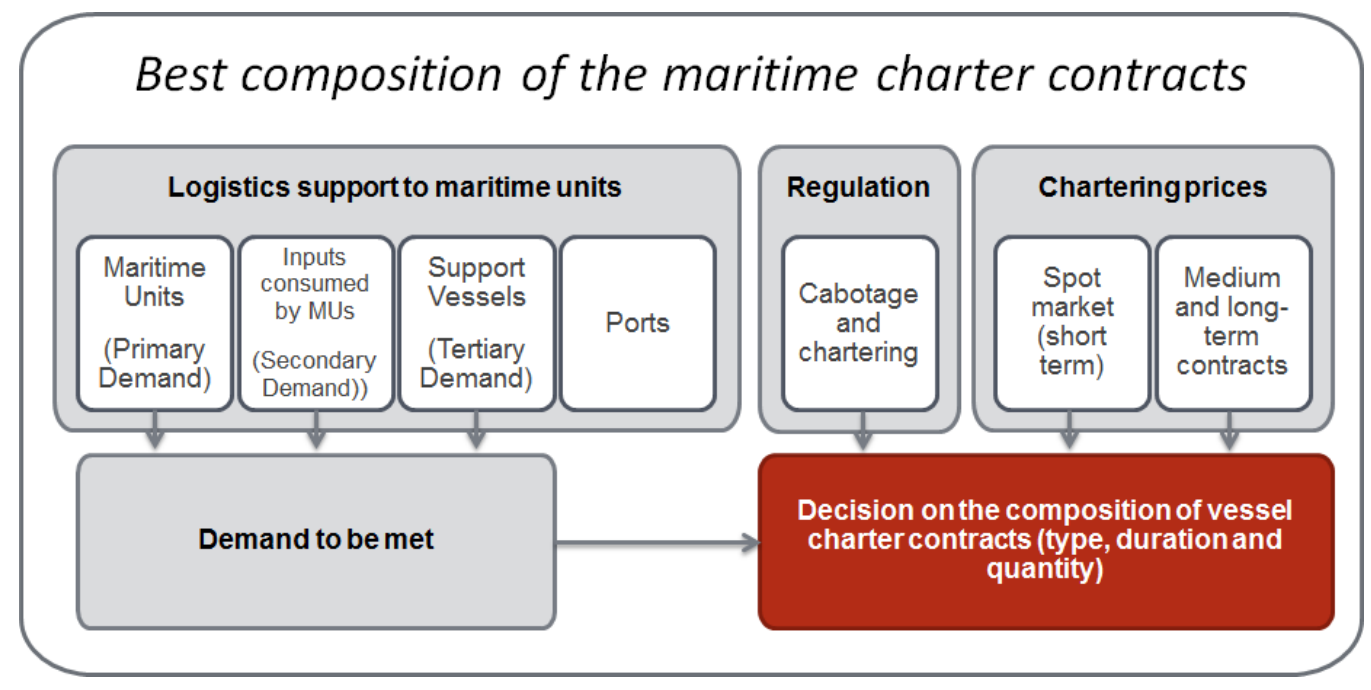

Figure 1. Factors determining the composition of charter contracts Font: Developed by the author

Offshore support operations consist of cargo transportation and storage activities carried out by vessels supporting E\&P services at MUs. From the logistic point of view, the offshore support operations cover the handling of loads of weights, formats and varied types, as well as the planning of vessels with different specialties, service rules and operational restrictions [7-12]. According to Figure 1, the logistics of supporting the MUs, or offshore support logistics, is composed of four basic elements: maritime units; inputs (and services) consumed by MUs; support vessels; and maritime terminals [8].

In order to carry out vessel planning, it is necessary to know the demand behavior, which can be broken down into: demand for MUs (primary); demand for supplies of each MU (secondary) and demand for vessels (tertiary). The three levels of demand correspond to the first three elements of the logistics support shown in Figure 1.

Primary demand - the types and quantities of MUs depends on the company's oil and gas exploration and production plans. As for the MU classes, the three basic ones are: drilling rigs, stationary production units and special vessels [8].

Secondary demand corresponds to the consumption profile of each class of MUs. The main inputs demanded are: food for the crew, common general cargo (stored in containers), drilling and production pipes, chemical products, potable water, diesel oil, drilling fluid and cement [7].

Tertiary demand is the demand for vessels as such. Depending on the class of inputs to be transported, a certain type of vessel is required. The most used vessel is of the PSV type with different sizes of capacity and can carry different types of input. But in addition to the PSV, there are other types of vessels: the Utility Boat (UT), which is a small supplier, which, because it is faster than PSV, is used to deliver fast loads; Anchor Handling and Tug Supply (AHTS), which is mainly used for towing and positioning platforms, but can also be used in transporting supplies; the Crewboat (CB), which transports crew members to/from the MUs; and the Oil Spill Response Vessel (OSRV), which is used to combat oil spills. Other types of vessels can still be used in specific situations [7, 13].

Finally, in addition to the characteristics and specificities of offshore support operations and the demand to be met, the formation of the fleet of chartered vessels is also strongly impacted by short, medium and long-term charter prices and maritime transport legislation and regulations in the country where the activities are carried out. Long-term contracts tend to be cheaper than short-term ones, but a large number of long-term contracts makes the fleet inflexible to fluctuations in E\&P demand, reducing the competitiveness of the oil company. In addition, there are rules and restrictions that must be observed. In Brazil, according to Normative Resolution No. 01/2015 of the National Agency of Waterway Transportation [9], the water transport of cargo in cabotage navigation must be carried out by a Brazilian shipping company using a Brazilian flag vessel. Exceptions are provided in that standard. This requirement has a significant impact on chartering decisions.

Uncertainties related to demand and chartering prices need to be considered in the problem. The company must have at its disposal a fleet of vessels sufficient to meet the demands of the maritime units. Due to changing scenarios - changes in demand and charter prices, regulation and the company's own objectives - the fleet needs to be flexible, with the risk of incurring incompatible costs. However, other players also act in the market, seeking to contract suppliers according to their strategies. Therefore, under certain conditions, supply may become scarce, resulting in significant increases in vessel contract values. Therefore, defining and managing the mix of charter contracts is a fundamental task for the competitiveness of an oil company. Developing a robust approach to support this decision-making is a problem that still requires study and proposition of methodologically supported solutions in the scientific method, presenting academic and applied relevance [14-15].

This article reviews the literature on the search for solutions to the problem of determining the most appropriate composition of charter contracts for the ongoing process of 
renewal of a specific fleet of vessels dedicated to the supply of offshore oil exploration and production units.

The remainder of this article is organized as follows: the next section describes the criteria used to search for publications, and then it is presented the bibliographic review of the approaches and methods best suited to solving the problem. The synthesis of the review carried out and a discussion on the main findings are presented in the fourth section. Finally, in the fifth section, the conclusions and suggestions for future work are presented.

\section{METHOD OF RESEARCH DEVELOPMENT}

The bibliographical research began with the broader theme of the problem: maritime chartering. The objective was to verify in the literature the types of problem of major interest related to this theme. Then, after understanding what the literature presents on the subject, we tried to identify among the works found those that most resemble the problem under analysis. In this first scan, an attempt was made to have an overview on the possibilities of ways to search for the best solution.

The keywords searched for in the review were chartering, affreightment, and freight in titles, abstracts, and keywords over the last 10 years at the Mendeley, Science Direct, and Scopus databases.

The search results are presented in Tables 1 and 2. Table 1 presents the search using the term chartering as a reference. There were 354 publications, of which 111 publications appeared in at least two of the databases, resulting in 243 different publications. Subsequently, the publications related to the maritime_sub-theme (maritime, sea, shipping) were identified, resulting in 79 publications of the 243 .

As for freight, the searches resulted in an excessive amount of publications: only in the Scopus base were found more than 10 thousand publications. Therefore, it was decided to reduce the scope of the search for maritime freight We found 293 publications, with 60 repeated in at least two of the bases, resulting in 233 different publications. Table 2 presents the results from the term maritime freight.

In the two sets of publications considered (chartering and maritime freight), filters were applied related to possible solutions approaches to the problem: modeling (model, modeling, modelling); optimization (optimization, optimizing, optimisation, optimise, optimal); simulation; agent-based systems (agent based and multi agent); multicriteria analysis (multiple criteria, multi criteria, multicriteria); and contract of supply with options (supply contract with options, flexible supply options, supply chain and option contract). The results are shown in Tables 1 and 2.

It was also examined the existence of publications that contained some form of literature review in the two sets of publications, which resulted in 7 publications in each set.

The last phase of the research consisted in choosing, among the publications found, summarized in the tables above, a relevant set for the presented problem. For this, this review work was divided into four categories of publications.

Table 1. Bibliographic research: chartering, maritime chartering and subtopics related to solution approaches

\begin{tabular}{|c|c|c|c|c|c|c|c|c|}
\hline & \multirow{2}{*}{\multicolumn{3}{|c|}{ Chartering }} & Mendeley & Science Direct & Scopus & Total & Not repeated \\
\hline \multirow{13}{*}{ Chartering } & & & & 149 & 27 & 178 & 354 & 243 \\
\hline & \multicolumn{3}{|c|}{ Literature review } & 6 & 3 & 3 & 12 & 7 \\
\hline & \multicolumn{3}{|c|}{ Modelling } & 46 & 12 & 57 & 115 & 82 \\
\hline & \multirow{3}{*}{ Modelling } & \multicolumn{2}{|c|}{ Optimization } & 20 & 8 & 18 & 46 & 25 \\
\hline & & \multicolumn{2}{|c|}{ Simulation } & 8 & 2 & 15 & 25 & 17 \\
\hline & & \multicolumn{2}{|c|}{ Agent-based system } & 2 & 0 & 3 & 5 & 3 \\
\hline & Multicriteri & analysis & & 4 & 0 & 3 & 7 & 4 \\
\hline & \multirow{6}{*}{ Maritime } & Maritime & & 38 & 14 & 70 & 122 & 79 \\
\hline & & Literature $\mathrm{r}$ & view & 2 & 3 & 2 & 7 & 3 \\
\hline & & \multirow{4}{*}{ Modelling } & Modelling & 21 & 8 & 38 & 67 & 43 \\
\hline & & & Optimization & 15 & 5 & 20 & 40 & 23 \\
\hline & & & Simulation & 3 & 1 & 3 & 7 & 4 \\
\hline & & & Agent-based system & 2 & 0 & 2 & 4 & 2 \\
\hline
\end{tabular}

Table 2. Bibliographic research: maritime freight and subtopics related to solution approaches

\begin{tabular}{|c|c|c|c|c|c|c|c|}
\hline & & & Mendeley & Science Direct & Scopus & Total & Not repeated \\
\hline \multirow{5}{*}{ Maritime freight } & \multicolumn{2}{|c|}{ Maritime freight } & 105 & 25 & 163 & 293 & 233 \\
\hline & \multicolumn{2}{|c|}{ Literature review } & 5 & 3 & 3 & 11 & 7 \\
\hline & \multirow{3}{*}{ Modelling } & Optimization & 11 & 3 & 14 & 28 & 19 \\
\hline & & Simulation & 10 & 2 & 13 & 25 & 17 \\
\hline & & Agent-based system & 1 & 0 & 0 & 1 & 1 \\
\hline
\end{tabular}

For the first category, we searched for papers directly related to maritime chartering, which provided an insight into what are the most important problems for the sector and how the proposed problem fits into this context. Six articles were selected which, in general, review the literature and an analysis of the sector. The formation and behavior of chartering prices stand out as an important factor in the choice of charter contract types. Therefore, this topic is addressed as a subcategory within the problems of maritime chartering and seven articles were chosen. The last three 
categories relate specifically to the search for solution approaches to the problem. It has been found that optimization methods are the most used in transport and chartering problems. For that reason, the second category of articles corresponds to optimization solutions found in problems of this type, which can be directly applied to this problem. Eight optimization works were analyzed. The third category of articles encompasses other approaches to solving transport and chartering problems. Five papers were selected. Finally, the fourth category refers to solution approaches applied to other types of problems that, however, have some correlation with the proposed problem. For example, one of the considered articles addresses the problem of selecting an aircraft, which can be correlated to the problem of selecting types of chartering. Eight papers are selected whose solutions present potential application for part of the problem in question.

\section{LITERATURE REVIEW}

\subsection{Maritime chartering problems}

This section aims to provide an overview of the most prominent problems for the maritime chartering sector, and how the problem of offshore support fleet renewal through chartering fits into this context. Important aspects are analyzed both from the point of view of the suppliers of the maritime transport (vessels and services related) and the company that charters the vessels to use in their logistics activities. Due to the great relevance to the industry, the formation and behavior of charter prices are addressed prominently at the end of this section in a subsection entitled the maritime chartering market.

Ozer and Cetin [16] examined the choice of type of chartering by Turkish shipowners of general cargo and dry bulk, and the criteria that affect and determine this choice. The methodology used covers a review of the literature, interviews and in-depth research on the subject. The study shows that the type of charter preferred by Turkish shipowners is voyage charter party (VCP) and that shipowners consider the risk in selecting type of chartering, charterer reliability and ship operating conditions are the most important factors for the chartering decision.

Still on the shipowners' side, Álvarez-Sanjaime et al. [17], analyze vertical integration and exclusivity in freight shipping. The authors seek to show the strategic advantages that a shipping provider can gain from building their own maritime terminal. In the same issue of the journal, these authors published another article [18], this one about competition and horizontal integration in maritime transport. The article models the competition for freight of goods between the road and maritime sectors. In the horizontal integration model presented in the article, operators offer differentiated services and, through oligopoly, use economies of scale in the sector as a competitive advantage.

Pantuso et al. [19] present a bibliographical research on the problem of mix and dimensioning of the fleet in maritime transport, i.e. maritime fleet size and mix problem (MFSMP), also focusing on shipping companies. They point out that market fluctuations and frequent incompatibilities between capacities and demands by vessels show the relevance of the problem and the need for more precise tools and methods to support decision making. After analyzing the literature related to the problem and its variants and extensions, the article seeks to summarize the state of the art on the theme, highlighting the main contributions of previous research. The paper also seeks to identify important aspects that were not captured in previous research. According to the authors, most of the research works has focused on the initial composition of the fleet and has not considered market volatility. They say future research should focus more on fleet renewal, which needs to continually adapt to changing market conditions. Market-related uncertainties need to be considered in future works.

On the side of the charterer, the bibliographic review carried out by Siddiqui and Verma [11] covers two main areas: fleet management and charter contracts and options. According to the authors, at the strategic level of fleet management, Dantzig and Fulkerson [20] were the first to consider both fixed costs of fleet acquisition and variable transport costs; Jin and Kite-Powell [21] proposed a model based on optimal control theories to deal with the scheduling of vessel replacement and utilization; Meng and Wang [15] presented a dynamic programming model with scenario generation for the problem of multi-period fleet development and deployment; Fagerholt et al. [22] considered uncertainty in planning and developed a decision support methodology that combined Monte Carlo simulation for the parameter estimation and an optimization model for industrial shipping applications. At the tactical level, the authors cite Al-Yakoob and Hassan [23], who assessed charter contracts to facilitate routing and scheduling a fleet of heterogeneous vessels, and indicate the readings by Christiansen, Fagerholt and Ronen [24] and Christiansen, Fagerholt, Nygreen and Ronen [25]. Siddiqui and Verma [11] also point out that although much of the works on the subject indicates spot contracts in fleet adjustment decisions, complex contracts and their options are also being used for this purpose.

Dinwoodie et al. [26] attempt to synthesize maritime experts' perceptions of changing patterns of maritime oil freight flows to 2050 through a classic Delphi study. The debate covers the global maritime oil flows; and factors related to future, including economic growth, changes in the shipping market and haul lengths. Briefly, perceptions indicate a gradual reduction in long-range maritime freight of oil, mainly due to the increasing intolerance of fossil fuels and local sources of oil supply. This trend, if confirmed, could affect the oil supply market in the world and, consequently, the offshore support vessels chartering.

\section{References describing the maritime freight market}

According to Adland et al. [27], unlike the financial market, where the volume of transactions is large and the related assets are homogeneous, allowing the direct and almost continuous derivation of indices that measure the movements of prices, transactions in the maritime freight market are heterogeneous occurring at irregular and low frequency intervals. Each signed contract is typically different from the latter, as the technical specifications and route of each ship can be substantially different. For this reason, the construction of market indices is usually done by shipbrokers - who act as intermediaries between buyers and sellers of shipping. Despite the difficulties, it is possible to find in the literature some works on prediction and construction of maritime freight rates indices.

Nomikos et al. [28] discuss an extension of the traditional 
lognormal representation of the neutral risk of the dynamics of spot freight rates to a diffusion model with jumps of magnitudes and random arrivals. They then develop a stock option structure on the average spot freight rate, which are commonly traded in the freight derivatives market. By exploring the computational efficiency of the proposed pricing scheme, they calibrate the jump diffusion model using market quotes of options on the trip-charter route average Baltic Capesize, Panamax and Supramax Indices. They show that the jump-extended setting produces important model improvements over the basic lognormal setting.

Kavussanos et al. [29] investigate economic spillovers between the freight and commodity derivatives markets. The economic relationship tested relates the derivative price of the commodity transported with the derived price on the freight rate. High frequency commodity data is synchronized with freight data, and freight rates for different vessels are combined with portfolios of commodities that these ships carry. The results of this work can help improve the understanding of the mechanisms of information transmission between the commodity and freight markets.

In the oil transportation sector, according to Siddiqui and Verma [11], a variety of short to medium term charter contracts, such as single voyage spot charter and over-thecounter contracts, and freight futures contracts are traded on several freight exchanges. The authors point out, however, that because of the lower hedge efficiency and the difficulty of the market to deal with the demand for specific route contracts, the future contracts were replaced by the mostly over-the-counter freight agreements [30-31].

Adland et al. [32] propose a freight rate formation model in individual contracts that incorporates charterer and owner heterogeneity and the corresponding owner-charter effects for the VLCC and Capesize market. Although market conditions and routes remain the most influential covariates, these paper shows that charterers, owners and their equivalents are also significant microeconomic determinants of the freight rate level.

The Offshore Support Vessels (OSV) market is very different from the traditional long distance navigation market. This type of vessel supports crucial logistic activities for the exploration and production of oil and gas; OSV spot markets are highly dependent on local climate and nature, generating high volatility; vessels are quite heterogeneous in terms of technical specification and can carry different types of cargo at the same time (e.g. liquids, chemicals and general cargo). These peculiar characteristics make it difficult to create objective price indexes for the market and make the analysis of price formation for individual contracts an even more important task [27]. The limits imposed by the cabotage regulations of some countries restrict this activity, imposing conditions that are reflected in the supply, cost and time of closing contracts.

In his last article, Adland et al. [27] discuss the construction of price indexes for the OSV market. In this work, the authors estimate a hedonic price regression to generate an index based on heterogeneous data from the OSV freight market. According to the results obtained by the application of the method in a data set with more than 30,000 transactions, the spot freight rates increase with the engine power and transport capacity of the vessels. The market volatility is seasonal and positively correlated to both oil prices and production volumes.

\subsection{Optimization solution for similar problems}

The optimization methods were the most frequent methods in the papers on shipping and chartering, similar to the proposed problem. In this section, some of these works are presented.

Caramia and Dell'Olmo [33] discuss optimization methods applied to freight transport systems, with specific focus on multi-objective modeling. The purpose of the book is, according to the authors, to provide decision makers with methods and tools to implement multi-objective optimization models in logistics, combining theoretical aspects with specific applications. The book presents a chapter on maritime transport, but does not deal specifically with maritime chartering.

Meng and Wang [15] propose a planning problem of multi-period liner ship fleet for a container shipping company more realistic than the studies in previous literature. According to the authors, this type of problem has been studied for some decades, but due to the simplifications required by the solution approaches used, the modeling of the problem distances itself from reality. The proposed problem is formulated as a scenario-based dynamic programming model, consisting of a series of integer linear programming formulations for each single planning period; and the model can be efficiently solved by a shortest path algorithm on an acyclic network. The results obtained in numerical examples show that chartering ships is not always the best policy for a long-term planning horizon, although it is much cheaper than buying ships in the short term. The purchase of ships seems to be a more profitable investment in the long run.

Özpeynirci et al. [34] present a mathematical model that searches for the ideal multimodal transport plan by chartering to manufacturing companies for a given planning horizon. The model considers the options of transport by road and sea. Sea transport requires chartering at least one vessel between the candidate vessel and chartered vessels operate on several predefined routes during the planning horizon. The mathematical model is applied to a company that delivers its products to customers by road, and is considering the option of using multimodal transport. The company plans to charter ships annually and operate them between national ports. The authors made a sensitivity analysis on several cases and observed that the proposed plan does not change for moderate variations in the data.

Bakkehaug et al. [35] propose a new formulation of multistage stochastic programming for the strategic fleet renewal for shipping companies. The new formulation explicitly addresses uncertainty in parameters such as future demand, freight rates and vessel prices. Computational tests are performed, comparing different discretizations of stochastic variables and different sizes of planning horizon. It is shown that significantly better results are obtained when considering the uncertainties of future parameters, compared to the use of expected values.

In order to analyze and improve the freight transportation plan considering multimodal transportation, Tokcaer and Özpeynirci [36] develop a biobjective mathematical model, whose objectives are to minimize the total cost and the number of operations of handling (an indicator of operational difficulty). The model decides on the ideal multimodal transport plan, including ship chartering and decisions on the mode of transport. To obtain an overview of the trade-offs in the change of the transportation mix, the Pareto Frontier was 
generated. The model was tested in an instance of a real problem of a Turkish petrochemical company producing ethylene.

Pantuso et al. [37] dealt with the problem of fleet renewal and, in particular, the treatment of uncertainty in the maritime case. Their main contribution is to evaluate if the use of stochastic optimization brings, in fact, better results than deterministic models. The assessment was conducted on the case of Wallenius Wilhelmsen Logistics, one of the largest shipping companies in the world.

Wang et al. [38] also present a chartering problem involving the composition and deployment of the marine fleet, taking into account market uncertainties. The authors propose a two-stage stochastic programming model and present a computational study based on the case of Odfjell, a leading chemical transport company in Bergen, Norway. The authors seek to show how the charter plans produced can change according to the different modeling choices; and also why and how different charter plans affect the company performance.

Siddiqui and Verma [11] deal with the tactical planning of a tanker fleet. This article presents a similar problem with the proposed problem. Oil producers generally meet intercontinental demand through a fleet of ocean oil tankers that not only have very high fixed and operating costs but also present considerable financial risks due to the volatility of oil demand and local freight markets. Thus, most petroleum suppliers maintain a low capacity fleet and manage additional requirements by periodically adjusting a combination of various charter contracts and / or their purchase options. For the problem of periodic adjustment of the fleet, the article proposes a methodology based on the conditional value-at-risk for protection against extreme losses. More specifically, it develops a mixed integer nonlinear programming model, where parameters are estimated through Monte-Carlo simulation to minimize both chartering costs and associated financial risks. The proposed methodology was applied to several instances of the problem and it was noted that the full use of the combination of charter contracts and their purchase options significantly reduces the financial risk due to the volatility of the spot freight market. On the other hand, they substantially increase the company's specific risks (financial risk due to the uncertainties of the demands of oil and oil tankers).

\subsection{Other approaches to solving similar problems}

This section presents other solution approaches found in transport and chartering problems, which can be directly applied to the proposed problem.

Maisiuk and Gribkovskaia [39] address a problem of supply vessel planning for offshore oil and gas installations through discrete event simulation. The implementation of weekly supply schedules for offshore installations during the year is affected by climatic conditions, influencing on salling time and service duration at installations. When the contract vessel cannot complete a voyage before the start of the next planned voyage, a vessel from spot market must be hired to execute it. The problem is to evaluate alternative fleet size configurations, taking into account uncertainties in weather conditions and future spot market rates for support vessels.

Caramia and Dell'Olmo [33] cite the use of multi-agent approaches in modeling logistics problems. According to the authors, there are several documented experiments on the implementation of multi-agent systems to solve transport logistic problems, such as Bergkvist et al. [40], Buchheit et al. [41] and Burckert et al. [42]. However, as also pointed out by Davidsson et al. [43], most of these experiments refer to small-scale experimentation, conducted without using data from real-world problems.

Di Febbraro et al. [44] propose a model framework for cooperation in intermodal freight transport chains as multiactor systems. In this context, the problem of optimizing freight transportation is decomposed into an appropriate set of subproblems, each representing the operations of an actor that connects using a negotiation scheme. A discrete event model is developed to simulate the system on a continuous horizon basis to explain the dynamics of intermodal freight transport operations. This framework allows planning of intermodal transport chains driven by short/medium term events. The methodology is evaluated using a realistic case study, and the results are compared to the First-Come-FirstServed strategy, highlighting the significance of cooperation in systems operating close to capacity.

Sardis et al. [45] propose a semi-automatic e-chartering system in maritime markets. Using a multi-agent system distributed to the Internet Virtual Chartering Markets (MAVCM) in each seaport and satellite information of participating vessels, they provide a mechanism for semiautomatic control and the creation of e-chartering contracts services. The proposed system is based on maritime contracts between shipowners and charterers through the MAVCM infrastructure, maritime services and satellite monitoring.

Parthibaraj et al. [46] propose to develop a sustainable decision model for allocating the ship's capacity to meet shipping demand and to generate a route plan. The work uses multiagent system modeling and an iterative combinatorial auction mechanism with Vickrey-Clarke-Groves payments to insert economically effective ships in the age of information exchange systems. To address the computational complexity of the multiagent system model with auction mechanism, the article proposes an enumerative search algorithm.

\subsection{Approaches to related solutions}

The articles in this section present solution approaches applied to other problem types which, however, have some correlation with the proposed problem, i.e., that can be applied to similar parts of the problem.

Chou et al. [47] formulated a combined fuzzy multiple criteria decision making and optimization programming model to solve the container transportation demand split problem. There are two stages in this combined model: in the first phase, the rate of division of the container transport demand is calculated using the MCDM (multicriteria fuzzy decision method) method; while in the second phase, an optimization mathematical programming network model is proposed to determine the origin / destination (O-D) for import / export of containers. The use of the proposed model is demonstrated in a case study of Taiwanese ports.

Gomes et al. [48] address the problem of decision support for the selection of an aircraft faced by an airline that is investing in chartering regional flights in Brazil. The problem has eight alternatives to be evaluated under 11 different criteria, the measures of which may be exact, stochastic, or fuzzy. The technique chosen to analyze and then find a solution to the problem is the multicriteria decision support method, called NAIADE (Novel Approach to Imprecise 
Assessment and Decision Environments). The method used allows approaching the problems working with quantitative and qualitative criteria under uncertainty and imprecision. Another important advantage of NAIADE in relation to other multicriteria methods is its characteristics of not requiring a prior definition of weights by the decision maker.

Also on air transport, Ozdemir and Basligil [49] study the purchase of aircraft in a Turkish airline using fuzzy numbers. Multicriteria decision techniques, Fuzzy ANP and Choquet integral methods are used for the evaluation and the results of both algorithms are compared using Fuzzy AHP. The main contribution of the study, according to the authors, is to determine the interdependence between the main criteria and subcriteria, the nonlinear relationship between them and the environmental uncertainties.

Gomez_Padilla et al. [50] analyze the impact of an option contract for two companies in a supply chain: a retailer and a supplier. With an option contract, the retailer requests a number of units and has the right to modify your order if necessary. The paper presents a model for calculating the performance of an option contract in terms of contract value for the two companies involved. Two cases are analyzed: multiple suppliers and one retailer; and one supplier and one retailer. The performance improvement obtained using this type of contract is compared by simulation.

Using Stackelberg's staging model, which is established based on the assumption that freight forwarders are risk averse, Lei and Zhou [51] analyze the optimal air freight supply, the ideal quantity of option orders, and the options purchased quantity of the intermediary. The analysis shows that air cargo industry under risk aversion applying option contracts can effectively avoid the risks of cost increasing and spot price rising, as well as increase the revenue of the whole system and further reach the Pareto optimal of society.

Hellermann et al. [52] propose the use of option contracts to improve the profitability of cargo airlines, which faces high asset costs and substantial uncertainties on demand. The proposed model seeks to capture the main features of cargo trade between an airline and a freight forwarder and then obtain an optimal transport reservation policy. The model also looks at the impact of overbooking on airline vendor profitability. By applying the model to the real-life booking data of a major cargo carrier, the authors compare the contractual arrangements used by the company with those provided by the model; and analyze, through a numerical study, the impact of overbooking on the parameters of contract and on the profitability of the company.

The article by $\mathrm{Hu}$ et al. [53] considers a decentralized supply chain, with a retailer and a manufacturer, where the producer's production yield and the retailer's demand are both stochastic. At the beginning of the selling season, the retailer places an order and buys an option contract with the manufacturer. After the selling season, the excess demand is partially ordered and the retailer exercises his option order and then places an instant order for the backorders. The ideal ordering policy for the retailer and the corresponding production decision for the manufacturer are studied. Numerical examples are performed to show the impact of model parameters on optimal policies.

The research conducted by Nosoohi and Nookabadi [54] considers a supply chain consisting of one supplier and one manufacturer producing a type of product (e.g. innovative products) with a long lead-time of supply, a short selling season and a stochastic demand. The complete production of the finished product requires two processing operations: initial operation and final operation. The manufacturer performs the initial operation at a deterministic cost. The final operation can be performed by the manufacturer or assigned to an outside company through an auction process. At the time of the supply contract, the final cost of processing (FPC) is estimated as a stochastic variable. The uncertainty about the FPC is removed before the start of the sales period. The study conducted is an attempt to determine how the vendor should place supply orders within the wholesale price, placement, call, and bidirectional options framework. Option contracts offer the manufacturer the flexibility to adjust their initial orders by exercising options purchased after the FPC. Optimized orders were obtained with each option contract, in addition to the equations in which initial and optimal option orders are valid. According to the authors' analysis, if the realized FPC is higher (lower) than a specific level, the manufacturer should decrease (increase) their initial orders. These specific levels were obtained for all types of option contracts. Numerical analysis and managerial perceptions clarify the value of the option contracts considering different parameter settings.

\section{SUMMARY AND DISCUSSION}

In this section, a summary of the results found in the literature review is presented. In order to do this, we sought to relate the references analyzed throughout the article with the most relevant aspects to the problem and to the search of the solution of the problem. The choice of these aspects is based on the definition and characterization of the problem and its envelopment presented in the first chapter. Table 3 (Appendix) contains the description of each aspect and related publications. In addition to the most relevant aspects, the publications were also related to the different approaches and solution techniques encountered. See Table 4 (Appendix). Table 5 (Appendix) is a cross-referencing of tables 3 and 4, presenting the number of publications for each aspect /approach pair. The same publication can cover more than one aspect and also present more than one solution approach. There were 36 distinct publications (the publications prior to 2008 , referenced by other authors, did not appear in the tables). The following is an analysis and a discussion about what the literature offers about the problem and its envelopment.

In publications related to maritime transport, there is interest in themes such as: fleet sizing, ship routing and multimodal transport. The decision on the composition of types of charter contracts, when approached, is treated in a secondary way; except for the article published by Siddiqui and Verma [11].

Long-haul shipping is the type of shipping of most publications found on maritime chartering. Maritime offshore support, which is the subject of the proposed problem, is addressed only by Maisiuk and Gribkovskaia [39], who analyze the impact of uncertainties (weather conditions and freight rates) on travel times and planning of offshore support vessels (OSV); and Adland et al. [27], which present a discussion on the construction of price indexes for the OSV market.

Most of the work on maritime chartering involves studies on chartering price behavior and prediction [27-29, 32]. Only one paper deals with the problem of optimization of the 
composition of charter contracts: the article by Siddiqui and Verma [11].

In fact, the problem addressed by Siddiqui and Verma [11] addresses several aspects of the problem proposed in this paper: it is an optimization problem of the mix of charter contracts, which considers the uncertainties related to demand and charter prices and which seeks to minimize charter costs and associated financial risks. However, some important differences for modeling and for choosing the solution approach should be observed:

(1) The article deals with a fleet of oil tankers whose market (supply-demand ratio) of vessels is quite different from the market for offshore support vessels;

(2) In the article, the demand to be met by the fleet of ships corresponds basically to the demand for oil, a commodity of well-defined behavior. In the proposed problem, it corresponds to the number of maritime oil production and exploration units demanded by a certain oil exploration and production plan (strategic decision) and the inputs consumed by each maritime unit (the demands of the exploration units have high variability);

(3) The problem of the article considers an own fleet of ships to meet the regular demand, resorting to the chartering market or options only in case of necessity; in the problem that is the object of this work, the fleet is all chartered, with a certain annual renewal rate, with the aim of optimizing the mix of charter contracts in the renewal of the fleet over time; and

(4) The time analysis of the article is one year. The problem demands medium- and long-term chartering plans, with time periods longer than one year.

With respect to solution approaches, Siddiqui and Verma [11] developed a mixed integer nonlinear programming model with conditional risk value to minimize chartering costs and associated financial risks, and used Monte Carlo simulation to generate the stochastic parameters related to oil prices and demand and to the spot rates of chartering. They also used option contracts to mitigate risks due to uncertainties in demand and charter prices.

Also on chartering, two studies on the use of supply contracts with options in air freight supply were analyzed [51, 52]; two studies that use multiagent systems for e-chartering [45] and for capacity allocation and route planning [46]; a qualitative analysis of the criteria for choosing types of charter [16]; a work on multiciteria decision to select chartering aircraft [48] and another on multi-period planning and ship routing [15].

In the literature on chartering price behavior and prediction, most of the analyzes found consider the global chatering market. Specific requirements encountered in local markets that may affect price behavior - such as the priority for national flag vessels required in the Brazilian cabotage market - are not addressed.

The reliability and operating conditions of the ship were important aspects pointed out by Ozer and Cetin [16] in the choice of shipping suppliers. Like these, other qualitative factors pointed out by the transport taker must be considered in the search method for the adequate set of charter contracts.

Table 3. Relevant aspects versus publications

\begin{tabular}{|c|c|c|}
\hline Aspects to consider & Description & $\begin{array}{l}\text { Authors } \\
\end{array}$ \\
\hline Chartering problems & $\begin{array}{l}\text { Problems directly related to chartering theme } \\
\text { (maritime or not). }\end{array}$ & $\begin{array}{l}\text { Sardis et al. (2009); Lei and Zhou (2010); } \\
\text { Meng and Wang (2011); Ozer and Cetin } \\
\text { (2012); Nomikos et al. (2013); Hellermann et } \\
\text { al. (2013); Kavussanos et al. (2014); } \\
\text { Özpeynirci et al. (2014); Bakkehaug et al. } \\
\text { (2014); Gomes et al. (2014); Adland et al. } \\
\text { (2016); Adland et al. (2017); Siddiqui and } \\
\text { Verma (2017); Parthibaraj et al. (2018) [13 } \\
\text { PUBLICATIONS] }\end{array}$ \\
\hline $\begin{array}{l}\text { Maritime transport: offshore } \\
\text { support vessels }\end{array}$ & $\begin{array}{l}\text { Maritime transport market to support of E\&P } \\
\text { maritime units (OSV). The chartering of vessels } \\
\text { of this type is the focus of this work. }\end{array}$ & $\begin{array}{c}\text { Lopes (2011); Aguiar (2013); Ares (2013); } \\
\text { Maisiuk and Gribkovskaia (2014); Arpini } \\
\text { (2015); ABEAM (2017); Adland et al. (2017) } \\
\text { [7 PUBLICATIONS] }\end{array}$ \\
\hline $\begin{array}{l}\text { Maritime transport: long- } \\
\text { haul vessels }\end{array}$ & $\begin{array}{l}\text { Long-haul shipping market, mainly related to } \\
\text { commodities such as oil, natural gas and } \\
\text { derivatives. Most of the publications on maritime } \\
\text { chartering are concerned with long-haul shipping. }\end{array}$ & $\begin{array}{l}\text { Sardis et al. (2009); Meng and Wang (2011); } \\
\text { Dinwoodie et al. (2013); Álvarez-Sanjaime et } \\
\text { al. (2013a); Álvarez-SanJaime et al. (2013b); } \\
\text { Nomikos et al. (2013); Kavussanos et al. } \\
\text { (2014); Özpeynirci et al. (2014); Bakkehaug et } \\
\text { al. (2014); Pantuso et al. (2014); Adland et al. } \\
\text { (2016); Pantuso et al. (2016); Wang et al. } \\
\text { (2017); Siddiqui and Verma (2017); } \\
\text { Parthibaraj et al. (2018) [15 } \\
\text { PUBLICATIONS] }\end{array}$ \\
\hline Local charter market & $\begin{array}{l}\text { Many countries have strong restrictions on } \\
\text { cabotage shipping (including OSV) and, } \\
\text { consequently, chartering market. }\end{array}$ & $\begin{array}{l}\text { Lopes (2011); Ozer and Cetin (2012); Aguiar } \\
\text { (2013); Kavussanos et al. (2014); Arpini } \\
\text { (2015); Tokcaer e Özpeynirci (2016); } \\
\text { ABEAM (2017) [7 PUBLICATIONS] }\end{array}$ \\
\hline Reliability of suppliers & $\begin{array}{l}\text { The reliability of shipping suppliers (reputation } \\
\text { and capacity) is a relevant aspect for charterers. }\end{array}$ & $\begin{array}{c}\text { Ozer and Cetin (2012); Arpini (2015); } \\
\text { Parthibaraj et al. (2018) [3 } \\
\text { PUBLICATIONS] }\end{array}$ \\
\hline Price uncertainties & $\begin{array}{c}\text { Volatility of prices of different types of } \\
\text { chartering. }\end{array}$ & $\begin{array}{l}\text { Lei and Zhou (2010); Nomikos et al. (2013); } \\
\text { Pantuso et al. (2014); Kavussanos et al. } \\
\text { (2014); Bakkehaug et al. (2014); Maisiuk and } \\
\text { Gribkovskaia (2014); Di Febbraro et al. }\end{array}$ \\
\hline
\end{tabular}




\begin{tabular}{|c|c|c|}
\hline Aspects to consider & Description & \begin{tabular}{|l} 
Authors \\
\end{tabular} \\
\hline & & $\begin{array}{l}\text { (2016); Adland et al. (2016); Adland et al. } \\
\text { (2017); Wang et al. (2017); Siddiqui and } \\
\text { Verma (2017) [11 PUBLICATIONS] }\end{array}$ \\
\hline Uncertainty of demand & $\begin{array}{l}\text { Uncertainties related to the demand for maritime } \\
\text { transport: variability of demand for UM's and } \\
\text { consumption of each MU, and climatic factors. }\end{array}$ & $\begin{array}{c}\text { Fagerholt et al. (2010); Hellermann et al. } \\
\text { (2013); Hu et al. (2014); Pantuso et al. (2014); } \\
\text { Bakkehaug et al. (2014); Nosoohi and } \\
\text { Nookabadi (2016); Wang et al. (2017); } \\
\text { Siddiqui and Verma (2017) [8 } \\
\text { PUBLICATIONS] }\end{array}$ \\
\hline Chartering prices prediction & $\begin{array}{l}\text { Determination of chartering price indices in its } \\
\text { various modalities. }\end{array}$ & $\begin{array}{c}\text { Nomikos et al. (2013); Kavussanos et al. } \\
\text { (2014); Adland et al. (2016); Adland et al. } \\
\text { (2017) [4 PUBLICATIONS] }\end{array}$ \\
\hline Risk of not meeting demand & $\begin{array}{l}\text { Quantification of risk and impacts of not meeting } \\
\text { the demand }\end{array}$ & Siddiqui and Verma (2017) \\
\hline Associated financial risks & $\begin{array}{l}\text { Expected financial values of the market risks } \\
\text { (freight rates) and of the company (not meeting } \\
\text { the demand and underutilization of the fleet). }\end{array}$ & $\begin{array}{l}\text { Gomez_Padilla et al. (2009); Lei and Zhou } \\
\text { (2010); Hellermann et al. (2013); Siddiqui and } \\
\text { Verma (2017) [4 PUBLICATIONS] }\end{array}$ \\
\hline $\begin{array}{l}\text { Minimization of associated } \\
\text { costs }\end{array}$ & $\begin{array}{l}\text { The composition of charter contracts to meet the } \\
\text { company's maritime transportation needs should } \\
\text { be made at the lowest possible cost. }\end{array}$ & $\begin{array}{l}\text { Gomez_Padilla et al. (2009); Nosoohi and } \\
\text { Nookabadi (2016); Pantuso et al. (2014); } \\
\text { Bakkehaug et al. (2014); Wang et al. (2017); } \\
\text { Siddiqui and Verma (2017) [6 } \\
\text { PUBLICATIONS] }\end{array}$ \\
\hline Minimization of risks & $\begin{array}{l}\text { The minimization of the aforementioned risks is } \\
\text { also one of the objectives pursued by the } \\
\text { companies. }\end{array}$ & $\begin{array}{l}\text { Gomez_Padilla et al. (2009); Lei and Zhou } \\
\text { (2010); Hellermann et al. (2013); Hu et al. } \\
\text { (2014); Nosoohi and Nookabadi (2016); } \\
\text { Siddiqui and Verma (2017) [6 } \\
\text { PUBLICATIONS] }\end{array}$ \\
\hline $\begin{array}{l}\text { Optimization of the charter } \\
\text { contracts mix }\end{array}$ & $\begin{array}{c}\text { Determination of the appropriate mix of charter } \\
\text { contracts for types, quantities and contract } \\
\text { duration. }\end{array}$ & $\begin{array}{l}\text { Wang et al. (2017); Siddiqui and Verma } \\
\text { (2017) [2 PUBLICATIONS] }\end{array}$ \\
\hline Mix problems & $\begin{array}{l}\text { The problem of determining the most suitable } \\
\text { composition of charter contracts can be } \\
\text { understood as a classic mix problem, where the } \\
\text { best combination of diverse resources is sought. }\end{array}$ & $\begin{array}{l}\text { Fagerholt et al. (2010); Meng and Wang } \\
\text { (2011); Pantuso et al. (2014); Özpeynirci et al. } \\
\text { (2014); Bakkehaug et al. (2014); Maisiuk and } \\
\text { Gribkovskaia (2014); Tokcaer e Özpeynirci } \\
\text { (2016); Pantuso et al. (2016); Di Febbraro et } \\
\text { al. (2016); Wang et al. (2017); Siddiqui and } \\
\text { Verma (2017); Parthibaraj et al. (2018) [12 } \\
\text { PUBLICATIONS] }\end{array}$ \\
\hline $\begin{array}{l}\text { Optimization under } \\
\text { uncertainties }\end{array}$ & $\begin{array}{l}\text { Considering the uncertainties mentioned above, } \\
\text { the presented problem can be treated as an } \\
\text { optimization problem under uncertainties, for } \\
\text { which the literature presents some solution } \\
\text { techniques. }\end{array}$ & $\begin{array}{l}\text { Caramia and Dell'Olmo (2008); Fagerholt et } \\
\text { al. (2010); Bakkehaug et al. (2014); Pantuso et } \\
\text { al. (2014); Pantuso et al. (2016); Di Febbraro } \\
\text { et al. (2016); Wang et al. (2017); Siddiqui and } \\
\text { Verma (2017) [8 PUBLICATIONS] }\end{array}$ \\
\hline $\begin{array}{l}\text { Multiobjective / multicriteria } \\
\text { analysis }\end{array}$ & $\begin{array}{l}\text { The problem can be formulated as a } \\
\text { multiobjective problem (eg minimization of both } \\
\text { costs and risks) or as a multicriteria analysis } \\
\text { (prioritization of alternative modes of chartering). }\end{array}$ & $\begin{array}{c}\text { Caramia and Dell'Olmo (2008); Chou et al. } \\
\text { (2010); Gomes et al. (2014); Tokcaer and } \\
\text { Özpeynirci (2016); Ozdemir and Basligil } \\
\text { (2016) [5 PUBLICATIONS] }\end{array}$ \\
\hline
\end{tabular}

Table 4. Solution approaches versus publications

\begin{tabular}{|c|c|c|}
\hline Solution approach & Description & \begin{tabular}{|c|} 
Authors \\
\end{tabular} \\
\hline Qualitative analysis & $\begin{array}{c}\text { Analysis of the problem regarding concepts, } \\
\text { perceptions and related theoretical and subjective } \\
\text { aspects. }\end{array}$ & $\begin{array}{l}\text { Lopes (2011); Ozer and Cetin (2012); } \\
\text { Álvarez-Sanjaime et al. (2013a); Álvarez- } \\
\text { SanJaime et al. (2013b); Aguiar (2013); Ares } \\
\text { (2013); Dinwoodie et al. (2013); Pantuso et al. } \\
\text { (2014); Arpini (2015); ABEAM (2017) [9 } \\
\text { PUBLICATIONS] }\end{array}$ \\
\hline Price modeling & $\begin{array}{l}\text { Statistical and mathematical techniques for } \\
\text { predicting and constructing price indices. }\end{array}$ & $\begin{array}{c}\text { Nomikos et al. (2013); Kavussanos et al. } \\
\text { (2014); Adland et al. (2016); Adland et al. } \\
\text { (2017) [4 PUBLICATIONS] }\end{array}$ \\
\hline Heuristic methods & $\begin{array}{l}\text { Algorithms that provide solutions without a } \\
\text { formal quality limit, generally evaluated } \\
\text { empirically in terms of the complexity and quality } \\
\text { of the solutions. They are often used in } \\
\text { conjunction with other optimization methods to } \\
\text { improve the search for solutions. }\end{array}$ & $\begin{array}{l}\text { Caramia and Dell'Olmo (2008); Fagerholt et } \\
\text { al. (2010); Bakkehaug et al. (2014); Wang et } \\
\text { al. (2017); Parthibaraj et al. (2018) [5 } \\
\text { PUBLICATIONS] }\end{array}$ \\
\hline $\begin{array}{l}\text { Nonlinear mixed integer } \\
\text { programming }\end{array}$ & $\begin{array}{l}\text { Mathematical programming (optimization) where } \\
\text { the problem presents non-linear correlation } \\
\text { between variables, and part of the variables }\end{array}$ & Siddiqui and Verma (2017) \\
\hline
\end{tabular}




\begin{tabular}{|c|c|c|}
\hline Solution approach & $\begin{array}{l}\text { Description } \\
\end{array}$ & Authors \\
\hline & belongs to the set of integers. & \\
\hline Multiobjective optimization & $\begin{array}{l}\text { Optimization techniques for problems with more } \\
\text { than one objective function. }\end{array}$ & $\begin{array}{l}\text { Caramia and Dell'Olmo (2008); Chou et al. } \\
\text { (2010); Özpeynirci et al. (2014); Tokcaer and } \\
\text { Özpeynirci (2016) [4 PUBLICATIONS] }\end{array}$ \\
\hline $\begin{array}{l}\text { Dynamic programming with } \\
\text { scenario generation }\end{array}$ & $\begin{array}{l}\text { Dynamic programming seeks to solve the } \\
\text { optimization problem by analyzing a sequence of } \\
\text { problems that is simpler than the original problem. } \\
\text { This technique can be combined with the } \\
\text { generation of scenarios to solve problems under } \\
\text { uncertainties (stochastic problems). }\end{array}$ & $\begin{array}{l}\text { Fagerholt et al. (2010); Meng and Wang } \\
\text { (2011) [2 PUBLICATIONS] }\end{array}$ \\
\hline $\begin{array}{l}\text { Stochastic programming } \\
\text { (two or multi-stage) }\end{array}$ & $\begin{array}{l}\text { Stochastic programming seeks a solution that is } \\
\text { balanced for all possible realizations of } \\
\text { uncertainties. At each realization of uncertainty, } \\
\text { more information is available, which is known as } \\
\text { the stage. }\end{array}$ & $\begin{array}{l}\text { Bakkehaug et al. (2014); Pantuso et al. (2016); } \\
\text { Wang et al. (2017) [3 PUBLICATIONS] }\end{array}$ \\
\hline Simulation of Monte-Carlo & $\begin{array}{l}\text { Method of statistical simulation that allows } \\
\text { simulating a process that depends on random } \\
\text { variables, and generates sampling experiments. }\end{array}$ & $\begin{array}{l}\text { Fagerholt et al. (2010); Siddiqui and Verma } \\
\text { (2017) [2 PUBLICATIONS] }\end{array}$ \\
\hline Multiagent systems & $\begin{array}{l}\text { It addresses the problem (or part of it) as a system } \\
\text { composed of agents, which interact with each } \\
\text { other and with the environment and are capable of } \\
\text { autonomous actions to meet certain objectives } \\
\text { [55]. }\end{array}$ & $\begin{array}{l}\text { Caramia and Dell'Olmo (2008); Sardis et al. } \\
\text { (2009); Di Febbraro et al. (2016); Parthibaraj } \\
\text { et al. (2018) [4 PUBLICATIONS] }\end{array}$ \\
\hline Discrete event simulation & $\begin{array}{l}\text { Method for simulating the operation of a given } \\
\text { real system by means of discrete events that take } \\
\text { place over time. Also known as stochastic } \\
\text { simulation, it allows the use of stochastic } \\
\text { variables to represent the uncertainties inherent to } \\
\text { the modeling system. }\end{array}$ & $\begin{array}{l}\text { Maisiuk and Gribkovskaia (2014); Di } \\
\text { Febbraro et al. (2016) [2 PUBLICATIONS] }\end{array}$ \\
\hline Risk analysis & $\begin{array}{l}\text { Risk measures such as value-at-risk (VaR) and } \\
\text { conditional value-at-risk (CVaR), can be used to } \\
\text { represent the company's risk aversion policy. }\end{array}$ & Siddiqui and Verma (2017) \\
\hline $\begin{array}{c}\text { Multicriteria Decision } \\
\text { Analysis }\end{array}$ & $\begin{array}{l}\text { Methods of hierarchical analysis for problems } \\
\text { involving the choice of alternatives, which allow } \\
\text { the use of quantitative and qualitative data, } \\
\text { tangible or not, for the decision criteria analysis. }\end{array}$ & $\begin{array}{c}\text { Chou et al. (2010); Gomes et al. (2014); } \\
\text { Ozdemir and Basligil (2016) [3 } \\
\text { PUBLICATIONS }]\end{array}$ \\
\hline $\begin{array}{c}\text { Supply contracts with } \\
\text { options }\end{array}$ & $\begin{array}{l}\text { Also called flexible supply contracts, they bring } \\
\text { flexibility to the management of contracted } \\
\text { products and services. The use of options reduces } \\
\text { the risk of under-utilization and high costs due to } \\
\text { price volatility. }\end{array}$ & $\begin{array}{l}\text { Gomez_Padilla et al. (2009); Lei and Zhou } \\
\text { (2010); Hellermann et al. (2013); Hu et al. } \\
\text { (2014); Nosoohi and Nookabadi (2016); } \\
\text { Siddiqui and Verma (2017) [6 } \\
\text { PUBLICATIONS] }\end{array}$ \\
\hline Multi-approach solution & $\begin{array}{l}\text { Methods that combine more than one approach } \\
\text { aiming at the best solution to the problem. } \\
\text { (Heuristic methods combined with other methods } \\
\text { are not considered here) }\end{array}$ & $\begin{array}{l}\text { Fagerholt et al. (2010); Di Febbraro et al. } \\
\text { (2016); Siddiqui and Verma (2017) [3 } \\
\text { PUBLICATIONS }]\end{array}$ \\
\hline
\end{tabular}

The optimization techniques were the most used solution approaches in the maritime transport problems where the aspects pointed out in Table 3 were observed. Some techniques with great potential to be used in the proposed problem were identified, such as those that consider the uncertainties in the method itself: dynamic programming with scenario generation [15], multi-stage stochastic programming [35] and two-stage stochastic programming [38]; the technique that addresses uncertainties by combining different methods: mixed integer nonlinear programming, Monte Carlo simulation, and conditional risk analysis [11]; and those that consider more than one objective in the mathematical modeling of the problem: multi-objective optimization [33-34, 36-37].

Other approaches have also been found in this type of problem: discrete event simulation [39], which, in the modeling process, considers the uncertainties of the problem through events and stochastic variables determined by probability distribution functions; and multiagent systems [33, 44-46], where the agent paradigm is used in the control process of supply and demand for chartering.

Not related to the theme maritime chartering, we searched for works on approaches to treat similar problems to the proposed one. In the literature on multicriteria decision analysis [47-49], studies were found that combine multicriteria decision with optimization and a method that allows the use of quantitative and qualitative criteria decision-making. The work on flexible supply options, or contracts of supply with options [50-54] show that the use of option contracts can minimize risks related to uncertainty of demand and charter prices. 
Table 5. Number of publications by aspect (line) and solution approach (column)

\begin{tabular}{|c|c|c|c|c|c|c|c|c|c|c|c|c|c|c|c|c|}
\hline & 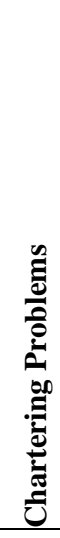 & 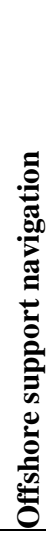 & 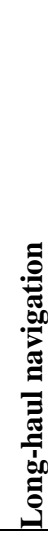 & 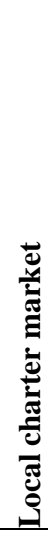 & 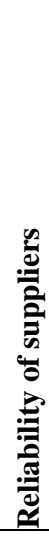 & 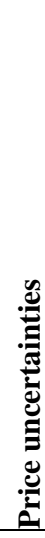 & 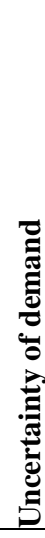 & 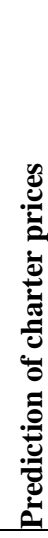 & 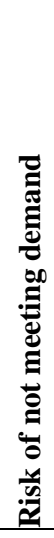 & 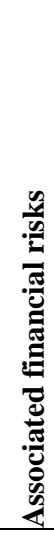 & 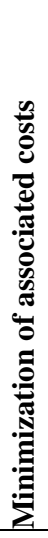 & 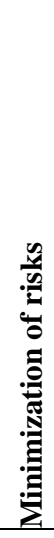 & 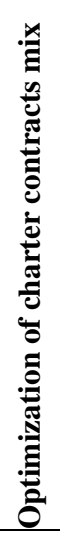 & 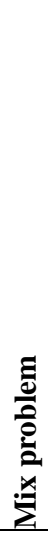 & 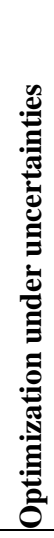 & 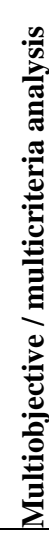 \\
\hline Qualitative analysis & 1 & 5 & 4 & 5 & 2 & 1 & 1 & & & & 1 & & & 1 & 1 & \\
\hline Price modeling & 4 & 1 & 3 & 1 & & 4 & & 4 & & & & & & & & \\
\hline $\begin{array}{l}\text { Heuristic/ metaheuristic } \\
\text { methods }\end{array}$ & 1 & & 3 & & 1 & 2 & 3 & & & & 3 & & 1 & 3 & 3 & 1 \\
\hline $\begin{array}{l}\text { Nonlinear mixed integer } \\
\text { programming }\end{array}$ & 1 & & 1 & & & 1 & 1 & & 1 & 1 & 1 & 1 & 1 & 1 & 1 & \\
\hline $\begin{array}{l}\text { Multiobjective } \\
\text { optimization }\end{array}$ & 1 & & 1 & 1 & & & & & & & & & & 2 & 1 & 3 \\
\hline $\begin{array}{l}\text { Dynamic programming } \\
\text { with scenario generation }\end{array}$ & 1 & & 1 & & & & & & & & & & & 1 & & \\
\hline $\begin{array}{l}\text { Stochastic programming } \\
\text { (two or multi-stage) }\end{array}$ & 1 & & 3 & & & 2 & 2 & & & & 2 & & 1 & 3 & 3 & \\
\hline $\begin{array}{l}\text { Simulation of Monte- } \\
\text { Carlo }\end{array}$ & 1 & & 1 & & & 1 & 1 & & 1 & 1 & & & & & & \\
\hline Multiagent systems & 2 & & 2 & & 1 & 1 & & & & & & & & 2 & 2 & 1 \\
\hline $\begin{array}{l}\text { Simulation by discrete } \\
\text { events }\end{array}$ & & 1 & & & & 2 & & & & & & & & 1 & & \\
\hline Risk analysis & 1 & & 1 & & & 1 & 1 & & 1 & 1 & 1 & 1 & 1 & 1 & 1 & \\
\hline $\begin{array}{l}\text { Multicriteria decision } \\
\text { analysis }\end{array}$ & 1 & & & & & & & & & & & & & 1 & & 3 \\
\hline $\begin{array}{l}\text { Supply contracts with } \\
\text { options }\end{array}$ & 2 & & 1 & & & 2 & 3 & & & 4 & 2 & 6 & & & & \\
\hline Multi-approach solution & 1 & & 1 & & & 2 & 2 & & 1 & 1 & 1 & 1 & 1 & 3 & 3 & \\
\hline
\end{tabular}




\section{CONCLUSIONS}

The optimization of the mix of charter contracts (types, quantities and duration) for fleet renewal, subject to uncertainty conditions related to the company (variation of demand) and to the market (variation of charter prices) is a problem of combinatorial optimization under uncertainties, difficult to be treated mathematically and computationally.

The objective of this research was to search the literature for possible solutions to the problem. In the area of maritime transport, there is great interest in issues such as fleet sizing and ship routing. On maritime chartering, most of the work is concerned with the formation and behavior of charter prices. In fact, this is a very relevant topic for the problem presented, but it is only one aspect to be considered. The article by Siddiqui and Verma [11] was the only work found on the optimal composition of charter contracts, which, as shown in the previous section, addresses several aspects but also presents important differences in relation to the problem studied.

The analysis of the characteristics of the problem and its envelopment and the findings of the literature review indicate that the construction of a solution multi-approach method is the best way to treat the complexity of this problem.

A qualitative approach is necessary for the preliminary analysis of the decision criteria and the information for the planning of the experiments. Multicriteria decision-making techniques were found that allow the use of qualitative and quantitative decision criteria. The demand to be met and the related uncertainties must be addressed at its three levels: number of E\&P UMs, which is a function of the company's plans for the future; consumption pattern of each type of UM; and, lastly, the number of vessels required, resulting from the two previous levels. The pricing prediction of the various types of charter is also fundamental for the choice of the mix of contracts. The search for methods of quality prediction is a subject much discussed in the literature. There is a consensus that this is not an easy task, especially for offshore support vessel markets, where local shipping restrictions and vessel diversity are considerable. Finally, for the decision of the optimal mix of charter contracts, considering the uncertainties related to the variables, several approaches and techniques with potential of use was identified, such as those that consider the uncertainties in the own method (dynamic programming with scenario generation, stochastic programming of two and several stages); those that consider more than one objective in the mathematical modeling of the problem (multiobjective optimization); and those that address uncertainties by combining with other methods (simulation, multi-agent systems, conditional risk analysis). The first two generally have good results, but they require great computational power when applied to very complex problems. In the combined methods, the processing capacity is mitigated by the greater flexibility of modeling. On the other hand, computational modeling and implementation are more laborious.

As a future work, it is suggested: (a) the study of price prediction techniques and the characteristics of a local market for offshore support vessels (prices, related variables, regulations, etc.) aiming at the development of a predictive model for this Marketplace; and (b) a more in-depth analysis of the solutions found in this work, aiming at the development of a multi-approach method that combines quantitative approaches with qualitative analysis approaches to adequately address the complexity of the problem.

\section{REFERENCES}

[1] IEA, World Energy Investment 2017. (2017). https://www.iea.org/publications/wei2017/, accessed on 15 June, 2019.

[2] ANP, Exploração e produção de óleo e gás. (2018). http://www.anp.gov.br/wwwanp/exploracao-eproducao-de-oleo-e-gas, accessed on 2 May, 2019.

[3] IHS Markit, Petrodata Offshore Rig Day Rate Trends. (2017). https://www.ihs.com/products/oil-gas-drillingrigs-offshore-day-rates.html, accessed on 6 May, 2019.

[4] IHS Energy, IHS Petrodata Offshore Marine Monthy January 2015.

(2015). https://www.ihs.com/products/offshore-marinemonthly-news.html, accessed on 8 May, 2019.

[5] ANP, Dados de E\&P. http://www.anp.gov.br/wwwanp/exploracao-eproducao-de-oleo-e-gas/gestao-de-contratos-de-ep/dados-de-e-p, accessed on 2 May, 2019.

[6] Ares G, Logística de apoio offshore - integração e sincronização da cadeia de atendimento às unidades marítimas,

ILOS. (2013). http://www.ilos.com.br/web/logistica-de-apoiooffshore-integracao-e-sincronizacao-da-cadeia-deatendimento-as-unidades-maritimas/, accessed September 13, 2017.

[7] Arpini BP, Planejamento da logística de suprimento de plataformas offshore por meio de um modelo matemático 2L - CVRP com frota heterogênea e equilíbrio náutico, Universidade Federal do Espírito Santo.

(2015). http://repositorio.ufes.br/bitstream/10/1688/1/PLANEJ

AMENTO DA LOG\%C3\%8DSTICA DE SUPRIMENTO DE PLATAFORMAS OFFSHORE POR MEIO DE UM MODELO MATEM\%C3\%81TICO 2L-CVRP COM FROTA HETEROG\%C3\%8ANEA E EQUIL\%C3\%8DBRIO N\%C3\%81UTICO.pdf.

[8] P.H.M. Lopes, Uma Solução para o Problema de Roteamento de Embarcações de Apoio "Offshore" Através da Metaheurística RTR, Universidade Federal do Rio de Janeiro. (2011). http://pee.ufrj.br/teses/textocompleto/2011101001.pdf.

[9] ANTAQ, RESOLUÇÃO NORMATIVA No 01ANTAQ, DE 13 FEVEREIRO DE 2015. (2015). http://antaq.gov.br/Portal/pdfSistema/Publicacao/Resolu coes_Normativas/20150806_Resolucao_Normativa_00 1_2015.pdf.

[10] Collyer, W.O. (2013). A importância do direito marítimo e da regulação dos transportes e portos para o desenvolvimento da logística. J. Transp. Lit., 7: 194201. http://dx.doi.org/10.1590/S223810312013000100012

[11] Siddiqui, A.W., Verma, M. (2017). A conditional valueat-risk based methodology to intermediate-term planning of crude oil tanker fleet. Computers \& Industial Engineering, 113: 405-418. http://dx.doi.org/10.1016/j.cie.2017.09.021

[12] Aguiar, R.A. (2013). Estudo do Impacto da Ampliação de Berço e de Área de Pátio no Aumento da Capacidade Operacional de uma Base de Apoio Offshore. 
Universidade Federal do Espírito Santo http://repositorio.ufes.br/handle/10/3963.

[13] A.B. das E. de A.M. ABEAM, Frota de Embarcações de Apoio Marítimo no Brasil - Agosto / 2017. (2017). http://www.abeam.org.br/, accessed on 2 May, 2019.

[14] Sawik, T. (2018). Supply chain disruption management using stochastic mixed integer programming. Springer International Publishing, Cham http://dx.doi.org/10.1007/978-3-319-58823-0

[15] Meng, Q., Wang, T. (2011). A scenario-based dynamic programming model for multi-period liner ship fleet planning. Transportation Research Part E: Logistics Transportation Review, 47(4): 401-413. http://dx.doi.org/10.1016/j.tre.2010.12.005

[16] Ozer, T., Cetin, I.B. (2012). A study on the charter type choice of Turkish General Cargo and Drybulk Shipowners. The Asian Journal Shipping Logistics, 28(2): 203-226. http://dx.doi.org/10.1016/j.ajsl.2012.08.004

[17] Álvarez-SanJaime, Ó., Cantos-Sánchez, P., MonerColonques, R., Sempere-Monerris, J.J. (2013). Vertical integration and exclusivities in maritime freight transport. Transportation Research Part E: Logistics Transportation Review, 51: 50-61. http://dx.doi.org/10.1016/j.tre.2012.12.009

[18] Álvarez-SanJaime, Ó., Cantos-Sánchez, P., MonerColonques, R., Sempere-Monerris, J.J. (2013). Competition and horizontal integration in maritime freight transport. Transportation Research Part E: Logistics Transportation Review, 51: 67-81. http://dx.doi.org/10.1016/j.tre.2012.12.008

[19] Pantuso, G., Fagerholt, K., Hvattum, L.M. (2014). A survey on maritime fleet size and mix problems. European Journal of Operational Research, 235(2): 341-349. http://dx.doi.org/10.1016/j.ejor.2013.04.058

[20] Dantzig, G.B., Fulkerson, D.R. (1954). Minimizing the number of tankers to meet a fixed schedule. Naval Research Logistics Quarterly banner, 1: 217-222. http://dx.doi.org/10.1002/nav.3800010309

[21] Jin, D., Kite-Powell, H.L. (2000). Optimal fleet utilization and replacement. Transportation Research Part E: Logistics Transportation Review, 36(1): 3-20. https://doi.org/10.1016/S1366-5545(99)00021-6

[22] Fagerholt, K., Christiansen, M., Magnus Hvattum, L., Johnsen, T.A.V., Vabø, T.J. (2010). A decision support methodology for strategic planning in maritime transportation. Omega, 38(6): 465-474 http://dx.doi.org/10.1016/j.omega.2009.12.003

[23] Sherali, H.D., Al-Yakoob, S.M., Hassan, M.M. (1999) Fleet management models and algorithms for an oiltanker routing and scheduling problem. IIE Transactions, 31(5): 395-406 http://dx.doi.org/10.1023/A:1007502205917

[24] Christiansen, M., Fagerholt, K., Ronen, D. (2004). Ship routing and scheduling: Status and perspectives. Transportation $\quad$ Science, $\quad 38(1)$ : $\quad 1-18$. http://dx.doi.org/10.1287/trsc.1030.0036

[25] Christiansen, M., Fagerholt, K., Nygreen, B., Ronen, D. (2007). Chapter 4 Maritime Transportation. in: C. Barnhart, G. Laporte (Eds.), Transportation (Amst)., Elsevier, pp. 189-284. https://doi.org/10.1016/S09270507(06)14004-9

[26] Dinwoodie, J., Tuck, S., Rigot-Müller, P. (2013). Maritime oil freight flows to 2050: Delphi perceptions of maritime specialists. Energy Policy, 63: 553-561. http://dx.doi.org/10.1016/j.enpol.2013.08.068

[27] Adland, R., Cariou, P., Wolff, F.C. (2017). What makes a freight market index? An empirical analysis of vessel fixtures in the offshore market. Transportation Research Part E: Logistics Transportation Review, 104: 150-164. http://dx.doi.org/10.1016/j.tre.2017.06.006

[28] Nomikos, N.K., Kyriakou, I., Papapostolou, N.C., Pouliasis, P.K. (2013). Freight options: Price modelling and empirical analysis. Transportation Research Part E: Logistics Transportation Review, 51: 82-94. http://dx.doi.org/10.1016/j.tre.2012.12.001

[29] Kavussanos, M.G., Visvikis, I.D., Dimitrakopoulos, D.N. (2014). Economic spillovers between related derivatives markets: The case of commodity and freight markets. Transportation Research Part E: Logistics Transportation Review, 68: 79-102. http://dx.doi.org/10.1016/j.tre.2014.05.003

[30] Kavussanos, M.G., Visvikis, I.D., Batchelor, R.A. (2004). Over-the-counter forward contracts and spot price volatility in shipping. Transportation Research Part E: Logistics Transportation Review, 40(4): 273296. https://doi.org/10.1016/j.tre.2003.08.007

[31] Koekebakker, S., Adland, R., Sødal, S. (2007). Pricing freight rate options. Transportation Research Part E: Logistics Transportation Review, 43(5): 535-548. https://doi.org/10.1016/j.tre.2006.03.005

[32] Adland, R., Cariou, P., Wolff, F.C. (2016). The influence of charterers and owners on bulk shipping freight rates. Transportation Research Part E: Logistics Transportation Review, 86: 69-82. http://dx.doi.org/10.1016/j.tre.2015.11.014

[33] Caramia, M., Dell'Olmo, P. (2008). Multi-objective optimization. in: Multi-Objective Manag. Freight Logist., Springer London, London, 2008, pp. 11-36. http://dx.doi.org/10.1007/978-1-84800-382-8_2

[34] Özpeynirci, Ö., Üçer, K., Tabaklar, T. (2014). Multimodal freight transportation with ship chartering. Maritime Economics Logistics, 16(2): 188-206. http://dx.doi.org/10.1057/mel.2013.24

[35] Bakkehaug, R., Eidem, E.S., Fagerholt, K., Hvattum, L.M. (2014). A stochastic programming formulation for strategic fleet renewal in shipping. Transportation Research Part E: Logistics Transportation Review, 72: 60-76. http://dx.doi.org/10.1016/j.tre.2014.09.010

[36] Tokcaer, S., Özpeynirci, Ö. (2016). A bi-objective multimodal transportation planning problem with an application to a petrochemical ethylene manufacturer. Maritime Economics Logistics, 20(1): 72-78. http://dx.doi.org/10.1057/s41278-016-0001-4

[37] Pantuso, G., Fagerholt, K., Wallace, S.W. (2016). Uncertainty in fleet renewal: A case from maritime transportation. Transportation Science, 50(2): 390-407. http://dx.doi.org/10.1287/trsc.2014.0566

[38] Wang, X., Fagerholt, K., Wallace, S.W. (2017). Planning for charters: A stochastic maritime fleet composition and deployment problem. Omega, 79: 5466. http://dx.doi.org/10.1016/j.omega.2017.07.007

[39] Maisiuk, Y., Gribkovskaia, I. (2014). Fleet sizing for offshore supply vessels with stochastic sailing and service times. Procedia Computer Science, 31: 939-948. https://doi.org/10.1016/j.procs.2014.05.346

[40] Bergkvist, M., Davidsson, P., Persson, J.A., Ramstedt, L. (2005). A hybrid micro-simulator for determining the 
effects of governmental control policies on transport chains. Multi-Agent and Multi-Agent-Based Simulation, 236-247. http://dx.doi.org/10.1007/978-3-540-322436_19

[41] Buchheit, M., Kuhn, N., Muller, J.P., Pischel, M. (1992). MARS: Modeling a multiagent scenario for shipping companies. in: Eur. Simul. Symp., Society for Computer Simulation.

[42] Burckert, H.J., Funk, P., Vierke, G. (2000). An intercompany dispatch support system for intermodal transport chains. in: Proc. 33rd Annu. Hawaii Int. Conf. Syst. Sci., IEEE Comput. Soc, p. 10. http://dx.doi.org/10.1109/HICSS.2000.926672

[43] Davidsson, P., Henesey, L., Ramstedt, L., Törnquist, J, Wernstedt, F. (2005). An analysis of agent-based approaches to transport logistics. Transportation Research Part C: Emerging Technologies, 13(4): 255271. http://dx.doi.org/10.1016/j.trc.2005.07.002

[44] Di Febbraro, A., Sacco, N., Saeednia, M., Di Febbraro, A., Sacco, N., Saeednia, M. (2016). An agent-based framework for cooperative planning of intermodal freight transport chains. Transportation Research Part C: Emerging Technologies, 64: 72-85. https://doi.org/10.1016/j.trc.2015.12.014

[45] Sardis, M., Vouyioukas, D., Anagnostopoulos. I. (2009). Semi-automatic e-chartering through multi-agent systems and satellite IP networks. International Journal Internet Protocol Technology, 4(3): 193. http://dx.doi.org/10.1504/IJIPT.2009.028658

[46] Parthibaraj, C.S., Subramanian, N., Palaniappan, P.L.K., Lai, K.K.H. (2018). Sustainable decision model for liner shipping industry. Computer \& Operation Research, 89: 213-229. http://dx.doi.org/10.1016/j.cor.2015.12.005

[47] Chou, C.C., Kuo, F.T., Gou, R.H., Tsai, C.L., Wong, C.P., Tsou, M.C. (2010). Application of a combined fuzzy multiple criteria decision making and optimization programming model to the container transportation demand split. Applied Soft Computing, 10(4): https://doi.org/10.1016/j.asoc.2010.05.021
[48] Gomes, L.F.A.M., de Mattos Fernandes, J.E., de Mello, J.C.C.B.S. (2014). A fuzzy stochastic approach to the multicriteria selection of an aircraft for regional chartering. Journal of Advanced Transportation, 48(3): 223-237. http://dx.doi.org/10.1002/atr.206

[49] Ozdemir, Y., Basligil, H. (2016). Aircraft selection using fuzzy ANP and the generalized choquet integral method: The Turkish airlines case. Journal Intelligent \& Fuzzy Systems, 31(1): 589-600. http://dx.doi.org/10.3233/IFS-162172

[50] Gomez_Padilla, A., Mishina, T., Gomez Padilla, A., Mishina, T., Gomez_Padilla, A., Mishina, T. (2009). Supply contract with options. International Journal of Production Economics, 122(1): 312-318. http://dx.doi.org/10.1016/j.ijpe.2009.06.006

[51] Lei, L.C., Zhou, J. (2010). Stackelberg game model of capacity options for air cargo under risk aversion. Xitong Gongcheng Lilun Yu Shijian/System Eng. Theory $\quad$ Pract., 30: 264-271. https://www.scopus.com/inward/record.uri?eid=2-s2.077952383329\&partnerID=40\&md5=7533f45a0aa195f3 7dc4c52fea9c114a.

[52] Hellermann, R., Huchzermeier, A., Spinler, S. (2013). Options contracts with overbooking in the air cargo industry. Decision Science, 44(2): 297-327. http://dx.doi.org/10.1111/deci.12008

[53] Hu, F., Lim, C.C., Lu, Z. (2014). Optimal production and procurement decisions in a supply chain with an option contract and partial backordering under uncertainties. Applied Mathematics Computer, 232: 1225-1234. http://dx.doi.org/10.1016/j.amc.2014.01.149

[54] Nosoohi, I., Nookabadi, A.S. (2016). Outsource planning through option contracts with demand and cost uncertainty. European Journal of Operational Research, 250(1):

131-142. https://doi.org/10.1016/j.ejor.2015.10.030

[55] IEA, World Energy Investment 2017. (2017). https://www.iea.org/publications/wei2017/. accessed on 2 May, 2018. 